\title{
Beyond the Fears of the Pandemic: Reinventing the Nation-State?
}

\section{Pierre-André Taguieff}

But one cannot explain everything with facts, ideas, and words. There is, in addition, all one does not know and never will.

\section{- Louis-Ferdinand Céline ${ }^{1}$}

Once more, in politics, fearing has replaced planning. But this time the danger is not imaginary. The health crisis, coupled with an economic crisis, is probably the most severe one since 1929. As for the Enlightenment project of freeing people from fear and making them sovereign, ${ }^{2}$ it has been relegated to the museum of dead ideas. Fears proliferate, fueling fantasies and dictating behavior. The triggering event, the coronavirus

* Warm thanks to Annick Duraffour and Isabelle de Mecquenem for their comments. A short version of this essay previously appeared as "Pandémie, et si l'État-nation se réinventait?," L'Express, April 6, 2020, https://www.lexpress.fr/actualite/idees-et-debats/ pierre-andre-taguieff-pandemie-et-si-1-etat-nation-se-reinventait_2122871.html. Translated by Pierre Schwarzer.

1. Louis-Ferdinand Céline, La Vie et l'œuvre de Philippe Ignace Semmelweis (18181865), in Cahiers Céline 3, ed. Jean-Pierre Dauphin and Henri Godard (Paris: Gallimard, 1977), p. 78. [Translator's note: no translation available, thus the quotation has been translated along with the article.]

2. Cf. Max Horkheimer and Theodor W. Adorno, "Begriff der Aufklärung," in Dialektik der Aufklärung: Philosophische Fragmente (Frankfurt am Main: Fischer Taschenbuch Verlag, 1988), p. 9; English translation: Dialectic of Enlightenment: Philosophical Fragments, trans. Edmund Jephcott (Stanford, CA: Stanford Univ. Press, 2002), p. 1.

This is an open access article under the terms of the Creative Commons AttributionNoDerivatives 4.0 International (CC BY-ND 4.0) license. To view a copy of this license, visit https://creativecommons.org/licenses/by-nd/4.0. English translation (C) 2020 The TelosPaul Piccone Institute, http://www.telosinstitute.net. 
pandemic, brings us face to face with a highly anxiety-provoking conjunction: that of the inexplicable and the incurable - until further notice. This clashes head-on with the Prometheism of the moderns, which assumes that humanity only encounters problems it can solve. However, to succeed in explaining and mastering phenomena, one requires time, and fear only feeds impatience. The time of and for politics is utterly different from that of scientific research.

As the unforeseen occurs, so does uncertainty that, in conjunction with the perception of a lethal threat, fosters fear and sets up a dictatorship of urgency. And fear, paralyzing our capacity to imagine the future, tends to dictate its law to political leaders and ordinary citizens alike, with politicians believing they must reassure people and show them they know enough about the pandemic and are taking responsible actions against it. But the claim of explanatory omnipotence distorts the game: above all, it serves to comfort the public. An immodest power seeks to maintain the illusion that they have the situation under control.

The parades and prances of approved experts, however competent they may be, hardly conceal our ignorance and powerlessness. They also stir up a paradoxical malaise: what good is such expertise if it does not advance knowledge or seriously control the pandemic? Medical statistics should not be a substitute for biomedical research or serve as a cover-up in the absence of effective treatments.

It is as much about guarding oneself from a crippling catastrophism as it is about avoiding blind optimism. A truthful, lucid, and responsible intervention by a political leader would admit: "We do not know." But who among our politicians would dare to take the risk of the simple truth? Managing scarcity to better camouflage it or indefinitely postponing political decisions in anticipation of a "scientific consensus" is much easier. This is how, on April 9 of this year, the French government's press secretary (for the presidency), Sibeth Ndiaye, stated on the radio station France Info: "We will decide on a possible extension of the mandatory wearing of masks to the entire population as soon as we can build it on scientific consensus." She justified her statement by playing the French Academy of Medicine's recommendation of compulsory mask-wearing against the guideline of the World Health Organization (WHO), which "does not recommend the wearing of masks for the general population." This is a waitand-see attitude, ignoring the fact that, in the biomedical field, there can be no absolute consensus within the scientific community, which lives with 
the controversies through which research advances knowledge. Above all, however, it means that one takes for granted that political decisions must be scientifically based, that politics must cease to be an art and become an applied science. This is the illusion of scientism par excellence.

In situations of great danger (wars, terrorist attacks, natural disasters, epidemics), when questions of security and protection take precedence over all others, national sentiment returns to the surface and the "retreat" into the nation's borders becomes a major imperative for protection. The awakening of the tragic, the experience of suffering Necessity without Justice, impels, along with the feeling of an intractable conflict of values, a great return to reality, which must be confronted in all its terrible aspects. The sudden pervasiveness of death is a brutal reminder of our finitude, but also of the fact that as humans, we are social animals now living within the framework of nations rather than that of tribes or empires. National solidarity thus regains its meaning "from below," so to speak, silencing merchants of illusions and utopias, as well as the followers of a negative form of individualism, which is based on sanctified hedonistic and competitive values that undermine social ties under the cloak of openness. It should be noted, however, that while the feeling of a common threat unites or brings together, it can just as easily divide and oppose, depending on the associated passions and interests.

\section{A Critical Glance at the Tragic}

This brutal awakening of the tragic signals the defeat of the bright future promised by the secular religions. But it is a joyless tragedy. This is not a time for the rebirth of tragedy: we are less and less Greek, to overthrow a formula of Nietzsche. ${ }^{3}$ The merry tragic heroes are nowhere to be found. We only encounter the sad and tired ones. Fear and pity remain, but without accompanying moral sublimation. The tragic also lies in the rise of unsolvable dilemmas and problems: how can one respond effectively to the imperative of collective health without restricting individual freedoms? How can the economic machine be restarted without the suspension of prudential lockdown measures, that is, without endangering the lives of the most vulnerable? How can containment measures be justified when they reveal socioeconomic inequalities and risk exacerbating

3. Cf. Friedrich Nietzsche, The Will to Power, ed. Walter Kaufmann and R. J. Hollingdale (New York: Vintage Books, 1968), sec. 419, p. 226: "We are growing more Greek by the day." 
social envy? The tragic lies in the impossibility to justify once and for all the decisive choices: between health and the economy, between health and individual liberties.

This revival of the tragic, however, is accompanied by the awakening of critical thought, which, stripped of its ideological bias, at last focuses on sociohistorical realities. At the same time as the reality of borders, French citizens can come to acknowledge the importance of the sovereign state, gnawed away for several decades by the Europeanization of bureaucracy and a neoliberal globalization that goes hand in hand with deindustrialization, offshoring, and technological dependency. Hence the hysterical posturing of a French state now overtaken by events it had certainly neither foreseen nor even imagined; the elites in power having converted to an adaptationist gnosis, grounded in the belief that mankind's salvation lies in its ever-increasing adaptation to the boundless world market order, celebrated as a triumphant march toward prosperity and happiness for all. A transfigured headlong rush, illustrating the "legitimation through the future" analyzed recently by Marcel Gauchet. ${ }^{4}$

The forced march toward adaptation at all costs, under the pretense of "reform," was to be accomplished by the government of experts formed around President Macron, orchestrator of this new attempt to realize reason in history. But the resulting outcome is rather that of an involuntary display of incompetence and impotence. The actions of this government have been marked by a series of resignations or defections, as well as by successive turns, above all rhetorical, fueling the mistrust of its citizensa growing one, apparent for many years now, between the rulers and the ruled. ${ }^{5}$ This wariness affecting many democratic societies is burdened by an anger that, in times of lockdown, is manifested by gestures of humor, in France as elsewhere. This is the case, for instance, in Spain, devastated by the pandemic, where people loudly beat their saucepans on their balconies in protest against the government.

Like many Western governments, French political leaders have been fumbling around, multiplying their contradictory injunctions, one glaring example being when they chose not to postpone the municipal elections

4. Cf. Marcel Gauchet, The Disenchantment of the World, trans. Oscar Burge (Princeton, NJ: Princeton Univ. Press, 1992), pp. 172-90.

5. Cf. Luc Rouban, La démocratie représentative est-elle en crise? (Paris: La Documentation française, 2018); Pascal Perrineau, Le grand écart: Chronique d'une démocratie fragmentée (Paris: Plon, 2019). 
just when the official discourse turned to alarmism. Today, the conquering discourse of the first years of Macron, turned toward the bright future of the start-up nation, is giving way to a dramatization of the situation reflected in a martial discourse, adapted to a foreseeable dark future-after the health crisis, the economic catastrophe, or the recession on the horizon. Tragedy gives way to catastrophism, to a "twilight vision of the world." The image of a march toward chaos gives rise to deep pessimism, nurtured by a despair so severe it could translate into violent revolts and an intensification of social conflicts. As for fear, it favors the lifting of moral barriers and, for example, drives some distraught citizens to denounce their neighbors for violating the rules of the lockdown, a now commonplace practice.

On March 16, 2020, in a solemn address to the nation, President Macron repeated several times: "We are at war." A new, unforeseen, invisible and elusive, unfamiliar, resistant, and mutant "enemy" was thus added to the list of our foes, our secular demonology renewed through biology and medical care. As a result, our political imagination expands in equal measure with our weakened grip on reality. If, in the modern age, "health has replaced salvation," then illness has replaced eternal damnation. Demons are now called "viruses." But this is a strange "war," since the enemy is unknown and only one side, the human side, has victims. The war metaphor here is misleading. But it serves to rally the troops.

Widespread lockdown seems to be the only overall response to the health challenge, in the absence of systematic screening and vaccination. Nothing really new, since the coercive measures taken to address the major epidemics of the past, from quarantine to a sanitary control of ships, as the Black Plague (1347-1349) and the Plague of Marseilles (1720-1722), illustrate among others. Although it is not a cure and only serves to prevent hospitals from overloading, general lockdown has been turned into a compulsory miracle cure, prescribed as part of the government's medical catechism. This means that besides the collateral economic damage and the negative psychological effects that lockdown induces (stress, depression, emotional fatigue, etc.), one of the perverse effects of general lockdown is being ignored: the majority of the population is prevented from developing neutralizing antibodies, thus blocking their immunization. It must be

6. The formula (from 1860) stems from the physician and historian of science José Miguel Guardia (1830-1897) and is quoted by Michel Foucault in The Birth of the Clinic: An Archaeology of Medical Perception, trans. A. M. Sheridan Smith (New York: Routledge, 1976), p. 198. 
acknowledged, however, that it is not scientifically established that herd immunity can be acquired. According to studies in China and the United States, COVID-19 could attack the human immune system, destroying the $\mathrm{T}$ cells that are supposed to protect the body from harmful invaders. ${ }^{7}$ This is another example of the limitations of our knowledge of COVID-19.

There is a real problem here, stemming from a conflict of norms. As the historian Patrice Bourdelais reminds us, while it is true that "for centuries, the history of progressive scientific findings has contributed to imagining the possibility of eradicating infectious diseases," medical optimism in this area now comes up against the emergence of new diseases, on the rise since the 1980s. As a result, "the progress of science in the understanding of living organisms leads us to believe the eradication of infectious diseases is simply impossible and that we must try to control the spread of new epidemics as best we can." ${ }^{8}$ Control, not eradicate: by this rule of practical wisdom, we recognize the limits of the Prometheism of the moderns.

As in most European countries, since March 2020, all that Macron's government has accomplished is preaching petty lessons in morality and hygiene for infantilized citizens and the mere performance of power to intimidate or console people - the old progressive refrain of a better tomorrow rings hollow. ${ }^{9}$ Its representatives merely repeat the necessary rules of "social distancing" by stigmatizing the bad subjects worrying too loudly about their madly amateurish tinkerings, unprepared for a health crisis compounded by an economic crisis. The drop in GDP in the first quarter of $2020(-6 \%)$ has lead some political leaders to advocate for a gradual lifting of the lockdown without waiting for reliable tests to be produced. Those competing fears are dangerous, particularly because in their frenzy they supersede the much-needed focus on devising strategies to follow. Some doctors, such as Professor Jean-François Toussaint, propose

7. Stephen Chen, "Coronavirus Could Attack Immune System like HIV by Targeting Protective Cells, Warn Scientists," South China Morning Post, April 12, 2020, https:// www.scmp.com/news/china/society/article/3079443/coronavirus-could-target-immunesystem-targeting-protective.

8. Patrice Bourdelais, "La compréhension du vivant conduit à penser que l'éradication des maladies infectieuses est impossible," interview by Simon Blin, Libération, April 10, 2020, https://www.liberation.fr/debats/2020/04/10/patrice-bourdelais-la-comprehension-du-vivant-conduit-a-penser-que-1-eradication-des-maladies-infect_1784908.

9. Cf. Pierre-André Taguieff, L'Effacement de l'avenir (Paris: Galilée, 2000), pp. 26668; Taguieff, Le Sens du progrès: Une approche historique et philosophique (Paris: Flammarion, 2004), pp. 21-22. 
to move away from "blind" quarantine toward "personalized" quarantine, which implies the use of reliable tests. ${ }^{10}$ Such a selective quarantine cannot be carried out without systematic screening. The condition for responsible deconfinement is also mass screening, implying the availability of the required equipment. However, the expertocracy cannot stand any kind of opposition. Neither in the form of scientific controversy, nor in the form of a political debate based on respecting and listening to the adversary. But the facts are stubborn: thousands of French people are dying, and there is a shortage of effective protective masks, beds, respirators, and reliable tests - even sanitizer, gloves, and safety gowns are running low. No amount of rhetoric can transform or transfigure the harshness of reality.

For example, it turns out that France has been dependent on China for the manufacturing of pharmaceuticals and the production of face masks (in March 2020, French manufacturers produced 8 million face masks per week, while healthcare workers used 40 million in the same period of time). It must be acknowledged that, in this respect, the current French government is not the only one in this predicament and that France, with its public hospitals struck by austerity policies, was very poorly equipped to deal with such an epidemic (few intensive care beds, few molecular biology laboratories, etc.). The negligence of Western governments in the face of the pandemic is blindingly obvious. They began by underestimating the danger, implemented preventive measures with a delay, and did not hesitate to make reassuring statements based on approximate or unverifiable figures, sometimes purely and simply fake - as in China, ${ }^{11}$ Iran, or Turkey - and fallacious arguments - such as justifying the shortage of masks by claiming that they are of no use to ordinary citizens or that their use may even be dangerous.

For example, President Trump never ceased to minimize the danger of the pandemic by comparing it to the seasonal flu and by repeating that everything was "under control," that the country was "very well prepared," before panicking and totally changing his tune in the face of the increasing

10. Jean-François Toussaint, "Le confinement généralisé serait-il une erreur?," UP' Magazine, April 12, 2020, https://up-magazine.info/index.php/decryptages/analyses/45008le-confinement-generalise-serait-il-une-erreur/.

11. Cf., among others, Steven Lee Myers, "China Created a Fail-Safe System to Track Contagions. It Failed," New York Times, March 29, 2020, https://www.nytimes.com/ 2020/03/29/world/asia/coronavirus-china.html; François Danjou, “Affaibli à l'intérieur, le parti redore son blason dans le monde," QuestionChine, March 29, 2020, https://www. questionchine.net/affaibli-a-1-interieur-le-parti-redore-son-blason-dans-le-monde. 
number of COVID-19 deaths in the United States, and then declaring, as a worried businessman, that it was necessary to "reopen the country" as soon as possible. Let us also recall the unfortunate statements of Agnès Buzyn, then Minister of Health, first on January 21, 2020: "The risk of introducing this virus into France is low but cannot be excluded," then three days later: "The risk of importation is practically nil." On February 15, she declared that "it is necessary to prepare our health system for a possible pandemic spread of the virus," before announcing the next day her candidacy for mayor of Paris and resigning from her post as minister. On February 25, 2020, on the radio station RTL, the new Minister of Health, Olivier Véran, asserted that "there are no longer any sick people in circulation in France today." On the February 26, the football game between the Olympique of Lyon and Juventus of Turin, involving thousands of fans, was authorized in Lyon. As for President Macron, on March 7, he attended a performance at the Antoine Theater with his wife and encouraged the French, leading them by example, to continue going out in spite of the epidemic - so much so that at the end of the performance he declared: "Life goes on. There is no reason, except for the vulnerable populations, to change our habits of going out." In an even more worrisome fashion, on March 12, as he made an alarmist speech on the spread of COVID-19, affirming in particular that "the absolute priority for our nation will be our health," he nonetheless called on the French, piously grounded in "scientific advice," to go to the polls on March 15 in the first round of municipal elections: a major inconsistency, for which he is no doubt not the sole culprit. These messages were even more contradictory since, the day after the election, the same president announced quarantine measures for the entire country ${ }^{12}$ - not without urging companies to continue their activity "whenever possible" on March 19. It was not until March 16 that President Macron declared a "sanitary war" on COVID-19, which earned him a temporary increase in popularity, as measured by Ifop in a study carried out on March 19-20, 2020. We recognize here the phenomenon known as "rallying around the flag," that is, a patriotic rallying in the face of an international crisis, which is the case for the pandemic. ${ }^{13}$ But this effect is

12. Cf. Jean-Paul Moatti, "The French Response to COVID-19: Intrinsic Difficulties at the Interface of Science, Public Health, and Policy," Lancet, April 7, 2020, https://www. thelancet.com/journals/lanpub/article/PIIS2468-2667(20)30087-6.

13. Bruno Cautrès, "La 'start-up nation' semble terriblement démodée et vieux monde aujourd'hui...," interview by Arnaud Benedetti, Revue Politique et Parlementaire, 
generally short-lived and can be reversed if the crisis is prolonged without a clear way out. In an Ifop poll carried out on April 8-9, 2020, only $38 \%$ of French people trusted the government to effectively fight the pandemic - a six-point drop compared to the previous survey carried out on March 26-27. The legitimism of the French is often fleeting. However, as Jérôme Fourquet rightly notes, "what currently preserves the executive branch is that the other Western leaders, including populists, do not seem to be doing any better." 14

As for the unfortunate British prime minister, Boris Johnson, after downplaying the danger-and riding on the comforting idea that mass immunization should be allowed to develop - he had to acknowledge in early March 2020 that this was a "national challenge," without taking clear measures to deal with the pandemic. Less than a month later, the person who ostensibly shook hands in a hospital ("not even scared!") tested positive for COVID-19, before being hospitalized on April 5. All these senior political leaders have constantly sent contradictory messages, often reflecting the discords among the experts themselves. This can only increase the mistrust of political leaders, who sail on sight and enter the future backward. The demagoguery of those in power, masking their short-sightedness, uncertainty, and powerlessness with expert speeches under the sky of a scientism not unlike that of Homais, ${ }^{15}$ is obvious. The sacralization of "science" allows the rulers to cheaply relieve themselves of their responsibilities. The only science we get are mainly daily floods of statistics, which, depending on how we interpret them, worry or comfort us, inviting fantasies and rumors along.

The public's expectations toward the medical field increase with the feeling of a growing threat. The Raoult affair shows that, in situations marked by uncertainty and disarray, doctors who respond to the public's demand for therapeutic hope are seen as gurus, masters of truth, and

March 22, 2020, https:/www.revuepolitique.fr/la-start-up-nation-semble-terriblement-demodee-et-vieux-monde-aujourdhui/.

14. Jérôme Fourquet, "Covid-19: 'Cette épreuve collective révèle les fractures préexistantes de l'archipel français,'” interview by Eugénie Bastié, FigaroVox, April 5, 2020, https://www.lefigaro.fr/vox/societe/l-annulation-des-epreuves-du-bac-2020-repousse-1horizon-d-une-sortie-de-crise-20200405.

15. Monsieur Homais, pharmacist by trade, is a character in Flaubert's novel $M a$ dame Bovary (1857). This grotesque figure, blending definitive decisions with apothecary recipes, is known for his social vanity and scientific pretensions. He embodies a kind of "scientific" idiocy that has become widespread since the middle of the nineteenth century. 
saviors. They are endowed with a charismatic power comparable to that of famous healers or shamans. When they are not recognized and supported by the political and medical establishment, they appear both as Robin Hoods defying the ruling power and as benefactors to humanity. Replacing the reference to puerperal infection by the mention of the COVID-19 pandemic, one could attribute to Didier Raoult, with a zest of irony, these words of Philippe Ignace Semmelweis, quoted by Céline in his medical thesis: "Fate has chosen me to be the missionary of truth for the measures that must be taken to avoid and fight the puerperal scourge." ${ }^{16}$ The Raoult affair has the advantage of revealing the antagonism of two logics of action: that of the defenders of the scientific method, involving clinical trials that take time, and that of the supporters of therapeutic urgency, illustrating a pragmatic medicine of which Didier Raoult has become the champion. ${ }^{17}$ Here again we are treading on thin ice: the difficulty lies in avoiding both the scientific dogmatism of the medical bureaucracy and the demagogy of miracle workers, who do not hesitate to tap into the public's mistrust of "official science" cut off from the field, thus running the risk of feeding the imaginary conspiracy accompanying the health crisis ("they hide everything from us," "they take us for a ride," etc.).

Professor Philippe Gabriel Steg heavily criticized Didier Raoult's media stance, in particular his criticism of randomized trials, ${ }^{18}$ dismissed as unethical in an emergency situation, amounting to letting the argument of authority ("eminence-based medicine") prevail in medicine by disqualifying "evidence-based medicine":

What is presented as the fight of the "maverick" against the "ivory tower" is in fact exactly the opposite: to refuse the experimental method, verification, and replication is to return to the bygone era of ivory tower certainties, in which the authority and intuition of the boss were equal to proof. Conversely, medicine by evidence, derived from randomized

16. Céline, La Vie et l'œuvre de Philippe Ignace Semmelweis, p. 41.

17. Cf. Amélie Petit, "Hydroxychloroquine ou l'essai clinique à l'épreuve du Covid19," AOC, April 7, 2020, https://aoc.media/opinion/2020/04/07/hydroxychloroquine-oulessai-clinique-a-lepreuve-du-covid-19/.

18. In medicine, a randomized controlled trial is an experimental protocol that serves to evaluate the efficacy of a treatment, of a prevention measure, or of a drug. It consists in comparing an experimental group (also called intervention group) that is administered the treatment with a control group (or witness group) that has been administered either a standard treatment or a placebo. It prevents treatments from becoming subject merely to the whim of physicians. 
clinical trials, amounts to giving each and every researcher, every doctor, regardless of rank, country, or specialty, the possibility of experimentally testing a hypothesis, of verifying or invalidating it, of replicating the results - and, via peer review, of criticizing or moderating the conclusions drawn from them; a process of confronting doubts, opinions, and verification. ${ }^{19}$

The Raoult affair, which divides the French, exemplifying the populist pattern "the people against the elites," can be understood in its psychosocial dimension, characterized as follows by Jérôme Fourquet:

It is a classic feature of times of crisis that the bearers of good news arouse interest and sympathy. But the infatuation toward Prof. Raoult, encouraged by his skilled communication and positioning, is also based... on a movement already present during the "Yellow Vests" crisis: a severe mistrust of the given authorities, the opposition of the presumed pragmatism of the field to the supposedly disconnected elites, the province (Marseille) against Paris. ${ }^{20}$

In his public actions, President Macron likes to surprise. Such was the case when he secretly planned his visit to Didier Raoult at the University Hospital Institute in Marseille on April 9, 2020. It is true that this decision was made after the success of several petitions in defense of Professor Raoult, attacked by many of his peers. A great communicator, this doctor-researcher was already an "international star"- as he likes to point out himself-before the controversies over the treatment of COVID-19 patients with hydroxychloroquine. With hundreds of thousands of signature ${ }^{21}$ on petitions in favor of his proposed treatment, the pro-Raoult movement had become a mainstream political force to be reckoned with.

19. Philippe Gabriel Steg, "Coronavirus: trois premières leçons sur l'épidémie," April 11, 2020, Les Echos, https:/www.lesechos.fr/idees-debats/editos-analyses/exclusifcoronavirus-trois-premieres-lecons-sur-lepidemie-1194256.

20. Fourquet, "Covid-19."

21. Cf., among others, "Chloroquine: l'appel urgent d'un groupe de médecins," https://www.petition-chloroquine.fr/. On the morning of April 10, 2020, this petition had 354,309 signatures. Another petition, "Il faut écouter le professeur Raoult," https:// www.mesopinions.com/petition/sante/faut-ecouter-professeur-raoult/82737, was signed by 124,576 people. With regard to the pleas of medical professors, see "Traitement Covid-19: ne perdons plus de temps! \#NePerdonsPlusDeTemps," April 3, 2020, https://www.change. org/p/ephilippepm-traitement-covid19-ne-perdons-plus-de-temps-neperdonsplusdetemps, which had collected 468,167 signatures one week later. 
And his growing fame made him a formidable opponent and critic of government decisions. Hence the strategy of inclusion followed by the French president: to make this famous figure an ally rather than an enemy, ${ }^{22} \mathrm{dem}-$ onstrating that he has no enemies, apart from those he calls "nationalists" or "populists," with whom he does not argue. This communication strategy had been tested at the time of the mobilization of the Yellow Vests, through the organization of the "Great National Debate," launched on January 15, 2019. In a similar fashion, the April 9 visit to Prof. Raoult was intended to reactivate the image of a president who listens to the French, is intellectually curious and open to discussion. This unexpected visit can be considered a successful media coup.

However, we can observe a notable increase of public discontent, in late March and early April 2020, with Macron's management of the pandemic. As Pascal Perrineau and Guillaume Tabard noted, "the government is being blamed for concealing information, for its opaque communication, for responding too late, and for inadequately protecting those on the front line fighting the virus-related issues." ${ }^{23}$ Of the respondents to an Ifop survey in early April, 73\% believe that "the government has concealed certain information," 58\% that it "has not communicated clearly," $63 \%$ that it "has not allocated the proper resources to the infrastructures and health professionals to fight against the virus," and $70 \%$ that it "has not reacted quickly."

Mistrust of elites is the backdrop for the rising tide of conspiracy theories unleashed by the health crisis. And this mistrust is the shared premise of both the populist stance and the conspiracy mindset. Upon measuring the French population's support of conspiracy theories, one discovers that the openness to conspiracy theories is not evenly distributed. According to the survey carried out from March 24-26, 2020, by Ifop with Conspiracy Watch and the Jean-Jaurès Foundation, ${ }^{24}$ more than a quarter of the French

22. Guillaume Tabard, "Faire du professeur Raoult un allié plutôt qu'un ennemi," Le Figaro, April 9, 2020, https://www.lefigaro.fr/politique/guillaume-tabard-faire-du-prraoult-un-allie-plutot-qu-un-ennemi-20200409.

23. Guillaume Tabard and Pascal Perrineau, "Face à la crise du Covid-19, les Français entre colère, inquiétude et légitimisme," Le Figaro, April 10, 2020, https://www. lefigaro.fr/politique/face-a-la-crise-du-covid-19-les-francais-entre-colere-inquietude-etlegitimisme-20200410.

24. Rudy Reichstadt and Jérôme Fourquet, "L'épidémie dans l'épidémie: thèses complotistes et Covid-19," Fondation Jean-Jaurès website, March 28, 2020, https://jean-jaures. org/nos-productions/1-epidemie-dans-1-epidemie-theses-complotistes-et-covid-19. 
(26\%) adhere to the claim that COVID-19 is human-made and either intentionally $(17 \%)$ or accidentally $(9 \%)$ conceived in a lab. Those most prone to conspiracy theories are composed of, on the one hand, the youngest generations, often appropriating news indiscriminately and without verification, and, on the other hand, the most disadvantaged social categories, on average less qualified than the others and more tempted by alternative frames of interpretation, opposing "official truths" and postulating that "the truth is elsewhere." For example, $27 \%$ of people under 35 agree with the view that the virus was intentionally developed in a laboratory, compared with only $6 \%$ of those over 65 . Among the less wealthy, $22 \%$ agree with this thesis, while the more affluent ones only adhere by $4 \%$. Furthermore, when it comes to partisan sympathies, $40 \%$ of the supporters of the Rassemblement National [the main far-right party in France] believe COVID-19 was intentionally created in a laboratory, which is perfectly consistent with their systematic suspicion toward elites, supposedly irresponsible, corrupt, or criminal, as well as with the presumption that the true reasons for our ills are always hidden. Finally, the study establishes that being concerned about COVID-19 does not correlate with adhering to conspiracy theories.

In this matter, the braggarts claiming or suggesting they had seen the virus coming and would have drawn the right consequences had they been in power ought to be dismissed. Such boasting is simply childish. But it does not excuse the procrastination, the palaver, and the contradictory directives of our political leaders. In any case, it is hard to see how the irresponsible political and administrative leaders with regard to the health crisis could be held unaccountable.

\section{European Disunion, Disastrous Globalization, and National Sentiment}

One of the possible lessons one can draw from this pandemic is that the health of the citizens in each European nation, involving a general mobilization and a state of emergency - destined to remain temporary-must be placed above the "European values"-yet to be defined clearly - now sung by headless ducks gripped by the great fear of seeing their utopia fade away. The priority of life has destroyed the cozy illusions and wishful idealism. Who still believes the European Union can save anyone at all? That is the crux of the matter. No one would agree to die for "European values." In difficult times, the French sing the national anthem and not the European anthem. They can cooperate with this or that neighboring country, 
regardless of the heavy machine called the European Union. Europe is not a homeland; Europeans are not a people. They are not a community of destiny and responsibility, despite the flood of Europeanist rhetoric poured into discourse over the last three decades. People lulled by the European Union's rocking tunes are just good for wide-eyed daydreaming. In this respect, the responsibility of the elites is huge. They have indeed done everything they could to denationalize minds. But they have not succeeded in wiping out national sentiment.

Moreover, since the harm caused by offshoring and deindustrialization among the nations caught in the dream has now been acknowledged, deglobalization returns to the agenda as a condition for the survival of the human species. This does not of course entail suppressing all trade among nations: deglobalization can only be partial, which implies that choices must be made. But it is important to rethink economic exchange by topping it with protective rules. Insofar as it is never symmetrical, interdependence is a subtle form of dependence for the least powerful nations. Thus, savvy and selective protectionism may be necessary after the crisis ends. How could one not now want "French-made" products, especially when it comes to those that are vital for the country? How could we not firmly commit ourselves to a policy of reindustrializing France? President Macron himself, visiting a small business on March 31, 2020, stated: "Today's priority is to produce more in France." These words have a symptomatic value for a political leader attentive to shifts in public opinion.

If governing means forecasting, then many governments do not govern. We can assume the French want to be governed, and well governed, that is to say, in reference to the common good. If, moreover, to govern is to choose, then the Macron governance based on the acrobatic principle of sitting on both sides of the fence at the same time ["en même temps"] is doomed to keep ducking and weaving. One can only choose properly and make the right decision when priorities are clearly defined, which presupposes a hierarchy of values that today's coy political leaders would never dare to assert, stripped as they are of any sense of history. For to do so requires that the feeling for the state is married with that of nationhood. Where are Georges Clemenceau and Charles de Gaulle?

The utopia of a "happy globalization" has shattered against the rock of reality. For the pandemic can be seen in some respects as a pathology of globalization, a factor in accelerating the virus's spread. However, we must be careful not to completely attribute its rise to entirely unnatural causes 
so as to blame the culprits, always to be found among the "rulers" and the "powerful," according to the old "revolutionary" principle fashioned by the leftists of the 1960s and 1970s: "Everything is political." But one can also note that all partisans of "politically correct" verbiage are silent, a possible relief for the free-spirited. Our usual debates suddenly seem insignificant and can be dismissed as futile. In times of global lockdown, the paternalistic and compulsory preaching urging us to "live together" ["vivre-ensemble" is a politician's euphemism for "multiculturalism"] seems incongruous, especially since lockdown hasn't prevented civil society from rediscovering actual forms of mutual aid devoid of commercial intentions. The same holds true for the ritual celebration of multicultural societies, the objects of an ideological cult in the land of the intellectuals who "think well" and imagine the self-destruction of nations as the way to humanity's salvation. Postcolonial and decolonial "theorists" have nothing to say on the matter, except that, according to their chorus, the origin of our ills can only be the legacy of European colonialism and "white capitalism." The eco-disaster activists, while rejoicing in the improvement of air quality, see in the pandemic a "sort of ultimatum from nature," in the words of former TV presenter turned activist and politician Nicolas Hulot, who adds, reinforcing the most succinct anthropomorphism: "Nature sends us a message, it tests us on our determination." ${ }^{25}$ Humans would thus atone, by the propagation of the virus-monster, for their faults, the main one being their lack of ecological awareness. The neofeminist agitations and misandries on the model of the \#metoo or \#balancetonporc [a hashtag used to denounce sexual predators, translatable as \#snitchonyourpig] movement become derisory, even grotesque. One can only choke with laughter when one sees neofeminists improvising with gravitas on their unique theme: it is the patriarchy's fault. ${ }^{26}$ As for the anti-speciesist or animalist sermons on "animal welfare" and the commando operations of vegan fanatics, they seem insignificant or burlesque, even abominable. Sophisticated prattle comparing the welfare of the lion and the gazelle becomes obnoxious. For, if one takes the reasoning to the absurd, the "welfare" of the coronavirus involves the unhappiness and death of millions of humans. What can

25. "Nicolas Hulot: on assiste 'à un passage de cap de l'humanité,"” interview, BFMTV, March 22, 2020, https:/www.bfmtv.com/actualite/hulot-sur-bfmtv-on-assiste-aun-passage-de-cap-de-1-humanite-1880140.html.

26. Sandra Laugier, Pascale Molinier, and Patricia Paperman, "Nous défendre-face au discours politique sur le Covid-19," AOC, April 7, 2020, https://aoc.media/opinion/ 2020/04/06/nous-defendre-face-au-discours-politique-sur-le-covid-19/. 
we conclude from this, except that the circle of foolishness intersects here with that of criminality? The chimeras vanish, clearing the horizon.

In his address to the French on March 12, 2020, President Macron himself, seemingly returning to serious matters, made a strong reference to the idea of nationhood: "I am counting on you because the government alone cannot do everything, and because we are a nation." Borderless people of all political stripes come to recognize the need for border controls, even border closures, and strict adherence to those micro internal borders prescribed by the rules of quarantine. The pandemic could well have a positive effect, reshuffling the cards in many respects, provided we do not throw the baby (the democratic ideal) out with the bathwater (undemocratic neoliberalism). This predictable upheaval of the political sphere is of course not without danger, as it could awaken the desire for a clean slate. But this is a risk we must take, using a strong democratic foundation based on the French republican tradition ${ }^{27}$ as well as drawing inspiration from the experience of participatory or direct democracy in various coun$\operatorname{tries}^{28}$ — sometimes described as "populist." 29

What we know as specialty bias is illustrated by the "crisis exit" proposals made by intellectuals and activists who follow this or that redemptive utopia. The world's tireless "transformers" and "improvers" see in the pandemic a "major opportunity" to finally achieve the total change of their dreams. They all want, first and foremost, to destroy what they call "the system." The illusion of a clean slate is in line with the communist mythology dreaming of a "great night" that changed everything: for the absolute enemies of the "system," everything must be destroyed in order to rebuild it all on new foundations.

The bias of specialization finds itself ironically exemplified by the posture of a survivor of Marxism-Leninism-Maoism, Alain Badiou, a veteran of revolutionary simplification. In late March 2020, in a short essay entitled "On the Epidemic Situation," this preacher of communism quietly

27. Benjamin R. Barber, Strong Democracy: Participatory Politics for a New Age (Berkeley: Univ. of California Press, 1984); Pierre-André Taguieff, Résister au "bougisme": Démocratie forte contre mondialisation techno-marchande (Paris: Fayard/Mille et une nuits, 2001); Philip Pettit, Republicanism: A Theory of Freedom and Government (Oxford: Oxford Univ. Press, 1997).

28. Yannis Papadopoulos, Démocratie directe (Paris: Economica, 1998).

29. Cristóbal Rovira Kaltwasser, Paul Taggart, Paulina Ochoa Espejo, and Pierre Ostiguy, eds., The Oxford Handbook of Populism (Oxford and New York: Oxford Univ. Press, 2017). 
calls to work "for the transnational progress of a third stage of communism, after the brilliant stage of its invention and the strong and complex, but ultimately defeated stage of its state experimentation." ${ }^{30}$ This call to build a new bright future says nothing about the tens of millions of deaths due to the vast communist "experimentation" that was unfortunately "defeated" by ruthless external forces, the forces of evil (capitalism, imperialism, nationalism, etc.). The same refrain, on the opposite sidewalk, has long been hummed by the neo-Nazis, who imagine the Third Reich as a "state experiment" in Germanic racism and imperialism - with its "brilliant" beginnings in Pan-Germanism — an experiment that is also "strong and complex, but ultimately defeated" by demonic powers - "international Jewish finance" and "Jewish Bolshevism." Both are paving the way for their "third stage," which is supposed to realize their respective dreams of reworking human nature. Ideologized nostalgia, whether for Communism or National Socialism, not only erases the criminal past, it embellishes and transfigures it. And this decriminalization of totalitarian regimes, modern political translations of Prometheism, gives rise to plans to restart the totalitarian enterprise, sometimes under different names.

\section{Lucidity, Courage, and Solidarity}

However, there are signs, albeit weak and ambiguous, of a turning point that can be considered positive. With their backs to the wall, even the ruling elites who have had a global approach for a long time are wondering about national destiny, at least tentatively so. They call for national unity and solidarity, which in no way excludes, in principle, cooperation between sovereign nations - one that in no way implies the final fusion hoped for by the new cosmopolitans of the left or right. But sovereignty must first be regained and restored. And this must be done unambiguously. When President Macron, on March 31, 2020, called for "rebuilding our national and European sovereignty," his phrasing was confusing. Where then is the "European people" supposed to exercise so-called "European sovereignty"? ${ }^{31}$ European sovereignty is nothing but a sanctified chimera. By mechanically pretending that everything and its contrary can be done

30. Alain Badiou, "On the Epidemic Situation," trans. Alberto Toscano, Verso Blog, March 23, 2020, https://www.versobooks.com/blogs/4608-on-the-epidemic-situation.

31. Pierre-André Taguieff, "Emmanuel Macron, le président en marche vers 'l'Europe souveraine' ou la dernière utopie messianique en butte au réel," in Qu'est-ce qu'une nation en Europe?, ed. Éric Anceau and Henri Temple (Paris: Sorbonne Univ. Presses, 2018), pp. 283-324. 
"simultaneously," as Macron often says, only lame and nebulous syntheses can emerge. What needs to be reconstructed is national sovereignty.

Let us recall the great illusion shared by communists, anarchists, and neoliberals: that the state would disappear, and that it had to disappear for the greater good of the human race. As it posits the disappearance of conflicts in the world and thus the disappearance of any tangible enemy, the call for the "end of territories" and sovereignties was the meeting point of all the utopias of liberation, fueled by the promises of globalization: more exchanges and mixtures, and "openness" as a new moral imperative. The pandemic brutally reminds us, first of all, that the world is still not at peace, that it abounds in the most diverse threats, and second, that the sovereign state is the only effective instrument to "respond to the omnipresent existential threats" because it is the only body that can make crucial decisions. ${ }^{32}$ However, when the leaders of a nation-state are unable or unwilling to control national borders, or tolerate lawless zones within the national territory, they forsake state power. Defending the sovereign state means defending the freedom of citizens. A strong nation-state is in no way incompatible with a strong democracy: it gives it a framework in which it can flourish.

In recent years, in Europe, in the face of migratory pressure, we have seen not only a return of borders but also a demand for protective borders, a desire for better-controlled borders. ${ }^{33}$ The pandemic has given additional legitimacy to this demand while radicalizing it at once. In France, the imperative of reindustrialization has been imposed through the awareness of the country's extreme dependence on other countries for pharmaceutical products. This policy of reindustrialization implies the restoration of a sovereign and strategic state, capable of anticipation and concerned about the common good, which is defined on the basis of national interest and not in reference to the mystique of free trade without borders. There is no sovereignty without borders, no national community or national territory, if it is true that the border is "the perimeter of the exercise of sovereignty," as Michel Foucher puts it so well. Some people are worried about the emergence of a "neo-national world" that would feed on "neo-nationalist fevers," summarily labeled "far right" — a way of disqualifying them by

32. Russell A. Berman, "The Reemergence of the State in the Time of COVID-19," TELOSscope, April 9, 2020, http://www.telospress.com/the-reemergence-of-the-state-inthe-time-of-covid-19/.

33. Cf. Michel Foucher, Le Retour des frontières (Paris: CNRS Éditions, 2016). 
demonizing them through their reduction to a resurgence of "fascism." Foucher interprets the contemporary return of borders, sovereignty, and national sentiment as a return of the repressed, after the long intellectual and political domination of the ideology of "governance," linked to the cult of the post-national:

We are thus clearly emerging from a period of the disqualification of borders. I have always considered that... their negation carries the risk of a return of the repressed. That is what is happening to us today. And that is unfortunately what makes the far right so strong: in France in particular, we did not want to take the idea of nationhood seriously, we have diluted sovereignty in international cooperation and in the construction of Europe. Nation, sovereignty, borders, they are part of the same political category, which is supposed to disappear in the face of "governance."34

Let us note in passing that the controlled deglobalization we are entitled to hope for does not in any way imply playing the card of a degrowth policy, which, to satisfy a few radical ecologists, would be just as ruinous as unbridled globalization.

The supporters of border-abolition policies on both the left and the right are discovering the resistance of geopolitical reality, along with the hard truth of Aristotle's formula that "necessity cannot be convinced." The activists of the transnational leftist No Border network and the globalist or cosmopolitan voices of the "borderless world" remain speechless. The "borderless world" of their dreams becomes an increasingly unlikely possibility. The total abolition of the limits between "us" and "the others," between one inside and one outside, would transform the planet into a battlefield of all against all. Borders should not be seen as barriers, walls, or barbed wire, but as places of passage subject to rules. The total opening of borders would create not only a state of unbearable interdependence but also a permanent state of war between individuals and groups.

\section{A Few Lessons}

It is therefore necessary to further undo the demonization of the national fact and the deification of the post-national, to strip it of the allure of an

34. Michel Foucher, “\#Coronavirus. Avec la pandémie, nos stéréotypes sur les frontières sont remis en question," interview, Agrobiosciences, April 3, 2020, http://www. agrobiosciences.org/territoires/article/coronavirus-avec-la-pandemie-nos-stereotypes-surles-frontieres-sont-remis-en-question\#.XpB4dxQR190. 
emancipatory promise, even one of happiness for everyone. ${ }^{35}$ The stakes are clear: it is not a matter of abandoning the nation to xenophobic nationalists, those whom today's op-eds in a hurry call "populists," in a mixture of fear, ignorance, and contempt, a way of lazily amalgamating heterogeneous movements with contradictory orientations. One may hope that this will be the practical lesson drawn by the French from the terrible ordeal of the coronavirus pandemic. It may be that the question of the hour is that of sovereignism, but of a sovereignism no longer bound up with xenophobic nationalism and reinscribed in the republican tradition, itself rediscovered after three decades of attempts to disqualify it in the name of the multiculturalist model, the chimeras of cosmopolitanism, arrogant Europeanism, or any kind of identity-based communitarianism.

But this pandemic also reminds us that medical and hygienic advances, however real they may be, have not put an end to human vulnerability. The polymorphic artificialization of our existence does not protect us from epidemics. The pandemic brutally opens our eyes to one of the battles lost in advance by Promethean humanity, the one it is waging against aging, to the sound of trans- or posthumanist drums. ${ }^{36}$ If populations are aging due to advances in hygiene and medicine, they are also becoming more fragile. Such is the perverse effect of the lengthening of human life, as Gabriel Martinez-Gros points out: "COVID-19, which is taking tens of thousands of our elders, is twisting the knife in our wound: humanity is aging, and we are fighting a battle against death that we cannot win in the long run, as the age of our populations rises - and it will inevitably rise." ${ }^{37}$ This should encourage states to be strategic, to look beyond the short term and to use forward-looking analysis to prepare for challenging situations. Foresight should not be confused with prediction or prophecy.

Prometheus is less farsighted than he is presumptuous. Above all, he was powerless. His followers, the Moderns, proud to live in the age of globalization, discover with awe the limits of the omniscience and omnipotence they grant each other. The narcissistic wound is deep. But the truth emerges: the conquering progressivism that expects everything from

35. Cf. Pierre-André Taguieff, L'Émancipation promise: Exigence forte ou illusion durable? (Paris: Éditions du Cerf, 2019).

36. Laurent Alexandre, La Mort de la mort: Comment la technomédecine va bouleverser l'humanité (Paris: JC Lattès, 2011).

37. Gabriel Martinez-Gros, "Covid-19: la mélancolie de Donald Trump," April 10, 2020, Herodote.net, https://www.herodote.net/Covid_19_la_melancolie_de_Donald_Trumparticle-2648.php. 
techno-science and free trade offers little more than deceptive promises, arrogant admonitions, and consoling words. Science is too important to be left in the hands of those who sacralize and instrumentalize it with dubious intentions. It is time to desecrate it and to no longer expect salvation from the marvels of technology or the miracles of growth.

As to the "pragmatism" hastily deemed redemptive, this key concept of Macron supposed to open all doors and solve all problems, we now know it is but a nickname for opportunism and chameleonism. ${ }^{38}$ When one is first and foremost a showman, one can perfectly well play the role of a statesman as a professional. But this is just one of many roles played by Macron as well as by Trump, Bolsonaro, Johnson, and many other actors who have proven themselves on the political scene. And we know that in Ukraine a comedian, Volodymyr Zelensky, is a talented performer in the role of the head of state. None of them fits the famous definition of the President of the Republic proposed on January 31, 1964, by General de Gaulle: "The man of the nation, set up by itself to answer for its fate." The quest of power for its own sake and the taste for prestige for prestige's sake cannot bear the responsibility for a national destiny, or even imagine a great national design.

In his solemn address on April 13, 2020, President Macron emphasized his empathy and compassion for the French rather than the martial call to mobilize, without relinquishing his role as supreme leader in a dangerous situation. In a very measured fashion, he sketched out a selfcriticism: "Were we prepared for this crisis? Clearly, not enough." So it is not a mea culpa: the catastrophic mask management was "explained" by the global mask shortage or attributed to "weaknesses... in our logistics." His declarations of humility were offset by the pride of having achieved an initial success due to the lockdown measures: "The epidemic is starting to slow down." He especially made promises, regarding, among other things, masks and tests, for the period after May 11, the date set for the end of the general lockdown measures: "We will be able to test anyone who shows symptoms." And he ensured France was actively engaged in vaccine research: "our country is the country that has undertaken the most clinical trials in Europe."

This speech is far from putting to rest the uncertainties concerning the actual means to fight the pandemic. But it is of great interest in an entirely

38. Cf. Pierre-André Taguieff, Macron: miracle ou mirage? (Paris: Éditions de l'Observatoire, 2017), pp. 245-86. 
different matter: the call for "founding anew" and "reinvention" after the great "upheaval," the insistence on the independence of France, with patriotic and sovereignist accents. European "sovereignty" seems to have vanished from the horizon, at least for the time of a presidential speech in which the head of state dares to declare: "Let us reinvent ourselves, myself included." It remains to be seen whether the metamorphosis will take place or whether it will be a mere conjuring trick. Too much is known about President Macron's skills as an illusionist.

What we sorely lack are real statesmen apt to face the great historical challenges of the twenty-first century. We are in vain searching for possible heirs to the General de Gaulle or Winston Churchill. All we see when they lose their function of cognitive enlightenment to become instruments of manipulation are reincarnations of Louis XV "the Beloved," Louis XVIII "the Desired," or Napoleon the Small, in the apolitical age of communicators, social networks, and professional pollsters selling the new opium of the people. The cult of the majority's opinion-always assumed-by establishing the reign of media democracy, imperceptibly turned political actors into professional demagogues, surrounded by footmen and apparatchiks. There are few exceptions. Incarnations of the weak autocrat type are multiplying. In the face of Trump and his unchecked verbal impulses, in the face of Macron and his long, drawn-out speeches, Bergson's advice about political leaders is worthy of note: "Don't listen to what they say, look at what they do." 


\section{Timely. Provocative. Independent.}

Telos is a must-read for anyone with a serious interest in politics, philosophy, culture, and the arts. Subscribe now at www.telospress.com.
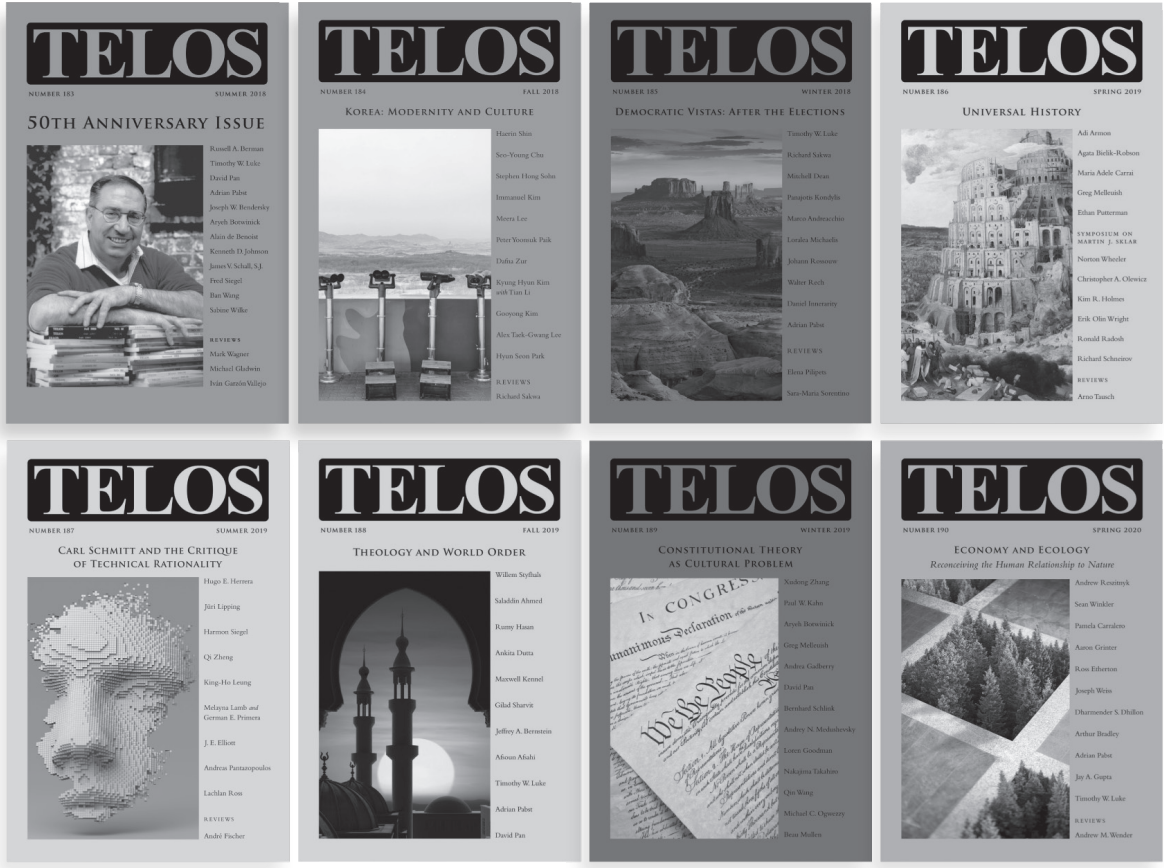

Since 1968, the quarterly journal Telos has served as the definitive international forum for discussions of political, social, and cultural change. Readers from around the globe turn to Telos to engage with the sharpest minds in politics and philosophy, and to discover emerging theoretical analyses of the pivotal issues of the day.



